\title{
Welfare-Spending Judgments Through Class, Race, and Gender Lenses: Exploring the Influence of Stratification Beliefs, Racial Attitudes, and Gender Norms
}

\author{
Eric Swank
}

\begin{abstract}
As politicians in the 1990s shrank welfare appropriations and tinkered with eligibility rules, many researchers examined American welfare attitudes. In doing so, separate lines of research argued that welfare-spending inclinations can be swayed by a person's class, race and gender statuses. Moreover, different studies connected welfare appraisals to a person's explanation of poverty, racial inequalities and gender hierarchies. As these inquiries provide critical insights these insights were hampered by a lack of theoretical breadth since they coalesced around a small set of independent variables. In effect, while theoreticians have linked class, race and gender matters, published quantitative works have routinely focused on only one set of class, race, or gender variables (i.e., numerous researchers consider welfare preferences in light of class and race interpretations as they neglect gender matters, or vice versa). In realizing that welfare attitudes probably emerge from all of these factors, this paper incorporates class, race and gender variables into a single explanatory model. With such a synthesis, this paper explores the welfare attitudes of college students from twelve randomly selected colleges $(n=575)$. In running a multivariate regression which explores the direct and separate contributions of each variable, the stu-
\end{abstract}

Eric Swank is affiliated with Morehead State University.

Journal of Poverty, Vol. 9(4) 2005

Available online at http://www.haworthpress.com/web/JPOV

(C) 2005 by The Haworth Press, Inc. All rights reserved.

doi:10.1300/J134v09n04_04 
dents' demographic affiliations seem to play a minimal role. Instead, attitudinal measures presented some significant results (especially the acceptance of modern racism, feminism and the belief of an open employment system). Thus, it seems that welfare antagonism was not contingent upon membership in certain race or gender groupings. Instead, welfare judgments were shaped by the perceived legitimacy of conventional class, race, and gender arrangements. [Article copies available for a fee from The Haworth Document Delivery Service: 1-800-HAWORTH. E-mail address: <docdelivery@haworthpress.com>Website: <http://www.HaworthPress. com> () 2005 by The Haworth Press, Inc. All rights reserved.]

KEYWORDS. Welfare policy, welfare reform, public support, social class, racial differences, stereotypes, sex differences, sex role attitudes

Although the US government may be a reluctant welfare state, it does provide a myriad of social programs. This maze includes social insurance programs, such as Social Security, which requires contributions from individuals before they can receive any benefits. The government also manages means-tested programs that presume a low income for eligibility. The federal means-tested program commonly called "welfare" directs benefits to poor children through a caregiving parent.

The last three decades have been inhospitable to public welfare programs and their clients. During this time, reductions in the scope and appropriations became routine and many states enacted their version of welfare reform. By 1996, the federal government drastically altered welfare policies through the passage of the Personal Responsibility and Work Opportunity Reconciliation Act (P.L. 104-193). This new law, among other things, ended the entitlement feature of public welfare, placed five-year time limits on welfare eligibility, and required some recipients to join community work programs in order to retain their benefits.

While this new law may have represented the wishes of Congress and President Clinton, there remains considerable uncertainty as to whether the US public would have ratified every stipulation of this law. For example, some research suggests that only about half of Americans favor time limits for welfare recipients (Pereria and Ryzin, 1998). Knowledge of public opinion is crucial since policy outcomes are shaped by the reactions of state legislators, front-line caseworkers, welfare recipients, employers, educators and many other stakeholders. Moreover, the perceived credibility of these reforms can influence the trajectories of fu- 
ture political mobilizations (McCrate and Smith, 1998; Krinsky, 2001; Reese, 2002).

The following paper investigates the sources of welfare spending attitudes. In drawing from diverse academic disciplines, this research strives for an exhaustive account. By testing a wide array of possible influences, this analysis incorporates 14 variables into its theoretical model. This comprehensiveness, along with multivariate statistical techniques, allows for some revealing explorations into the issues of spuriousness and causation. That is, researchers can identify which set of race, class and gender variables present a direct link to welfare attitudes when the other variables are held constant.

\section{THE DETERMINANTS OF WELFARE ATTITUDES}

In most opinion polls, a majority of Americans endorse the general principle of governmental relief for the poor and unemployed (Hasenfeld and Rafferty, 1989; Cook and Barrett, 1992). Yet, beneath this generic endorsement lies distinctive levels of support for specific programs. Americans seem to condone the social insurance programs that are geared to the disabled and elderly. In contrast, many Americans view welfare programs for the "able-bodied" with more ambivalence or disdain (AuClaire, 1984; Deitch, 1988; Hasenfeld and Rafferty, 1989; Sigelman and Welch, 1991; Gilens, 1995). For example, a 1988 sample found that only $3 \%$ of Americans wanted to cut spending on Social Security, whereas $16 \%$ wanted to cut public welfare and $24 \%$ wanted to limit Food Stamp spending (Cook and Barrett, 1992).

\section{Class, Race and Gender in Everyday Thoughts}

To most Americans, the issues of class, race, and gender are featured on a daily basis. The norms and controlling images of these topics influence the conceptions of oneself and others. In turn, these class, racial, and gendered notions can play a central role in shaping social policy attitudes (i.e., Kleugel and Smith, 1986; Kinder and Sanders, 1996). These notions can foster the perceived legitimacy of institutional practices and shape one's feelings for the beneficiaries of governmental programs. In the case of welfare, these notions can frame the debates over the extent and causes of poverty, and can inspire or dampen sympathy for welfare recipients and acceptance of governmental interventions on poverty matters (i.e., Cook and Barrett, 1992; Gilens, 1999). 
While theoreticians and qualitative researchers have noted the importance of class, race and gender intersections, quantitative studies have habitually treated class, race and gender cues as isolated forces. In doing so, researchers have confined their inquiries to one set of these factors and neglected the others. The ensuing literature review will elaborate these lines of research which have primarily centered on either the race, class or gender axises.

\section{Class and Welfare Attitudes}

The concepts of class and class consciousness of a person are fixtures in welfare attitudes research. One variant of class studies argues for the "self-interest" thesis (i.e., Alston and Dean, 1972; Cook and Barrett, 1992). This research assumes that lower and working-class peoples are aggravated by current economic conditions and their frustration accentuates the backing of redistributive agendas. Conversely, affluent and middle-class individuals might think that it is in their best economic interests to discredit any proposals that moderate current income distributions.

No matter how social class is operationalized, people of the higher stratums seem to find more faults with welfare. Studies grounded in self-identifications found that people who call themselves working class were more supportive on spending for the poor (Bobo and Kluegel, 1993). Likewise, studies that rely on occupational classifications derived similar results (Williamson, 1974; Jackman, 1994; Kinder and Sanders, 1996; Wilson, 2000). That is, professionals and entrepreneurs were more antiwelfare than blue-collar workers (Alston and Dean, 1972; Bullock, 1999) and unskilled blue collar laborers have sought greater welfare expenditures than skilled blue-collar workers (Kleugel, 1987).

Research also presents a modest yet durable relationship between income and welfare sentiments. Studies find that higher incomed peoples were less sympathetic towards disenfranchised families (Conover, 1988), embraced stricter welfare work requirements (Davis, 1988; Rexroat, 1993) and wanted smaller appropriations for food stamps, welfare and/or Medicaid (Feagin, 1975; Kleugel and Smith, 1986; Hasenfeld and Rafferty, 1989; Kinder and Sanders, 1996; Pereira and Van Ryzin, 1998; Gilens, 1999).

These income disparities seem to linger in different sub-populations. In a sample of women, Clark and Clark (1996) noted that only $11 \%$ of females from families with incomes over $\$ 50,000$ wanted to expand welfare spending while $52 \%$ of women from families with incomes un- 
der $\$ 15,000$ supported such actions (see also Deitch, 1988 or Stack, 1997). Other studies suggest that higher income blacks and Latinos were more adverse to welfare spending (Gilliam and Whitby, 1989; Sigelman and Welch, 1991; Montoya, 1996).

\section{Stratification Beliefs and Welfare Sympathies}

While class locations might induce certain welfare persuasions, so might the subjective side of economic interpretations. While researchers could have traced the effects of class consciousness or corporatist ideologies, much of the research has focused on the ways in which people explain the presence of poverty. In doing so, this research on "stratification beliefs" has drawn upon Joe Feagin's (1975) typology of inequality attributions. For Feagin, individualistic explanations locate the cause of poverty in the poor people themselves. In effect, poor folks are seen as deviants who cannot take advantage of economic opportunities since they supposedly engage in bad manners, excessive promiscuity, drug dependencies, criminality, insufficient work habits, etc. Structural explanations, in contrast, blame poverty on organizational shortcomings such as the lack of high paying jobs or the biases in school financing.

Welfare opponents seem to prioritize the importance of character flaws. During the 1960s the loudest War on Poverty dissenters ascribed poverty to laziness (Kallen and Miller, 1971; Alston and Dean, 1972), while later samples linked welfare complaints to the impression that poor people do "not try hard enough," "lacks the proper effort" and "rejects middle-class morals" (Williamson, 1974; Feagin, 1975; Kluegel and Smith, 1986; Iyengar, 1990; Cook and Barrett, 1992). Similarly, recent studies found citizens were more likely to disparage welfare when they thought poor people were listless, dumb or had "loose morals" (Pereira and Van Ryzin, 1998; Kick and Fraser, 2000; Sotirovic, 2000) and made no attempts at self-improvement (Zucker and Weiner, 1993).

Inside this individualistic orientation rests an assumed link between a person's work ethic and the "positive" side of inequality. That is, some of welfare's strongest skeptics insist that income inequality serves as an "incentive for work" and makes people "strive for professional success" (Bobo and Kleugel, 1993; Stack, 1997). Conversely, these same people believe that welfare dampens a person's desire to do intensive labor. On the other hand, antipathy towards cash transfer programs diminishes when respondents think inequality is destructive or they espouse structural explanations of poverty (Feagin, 1975; Kleugel and Smith, 1986; Cook and Barrett, 
1992; Bobo and Kleugel, 1993; Rexroat, 1993; Zucker and Weiner, 1993; Bullock, 1999; Sotirovic, 2000; Schlesinger and Heldman, 2001). For example, most people tend to seek larger welfare expenditures when they think that "economic differences are unjustified" and "few people are given equal chances" (Feldman and Zaller, 1992). Likewise, respondents from California, Illinois and Georgia wanted a stronger "welfare safety-net" when they were bothered by the negative outcomes of income polarization (Zucker and Weiner, 1993; Littrell and Diwan, 1998; Sotirovic, 2000).

\section{Race and Welfare Perspectives}

From the days of slavery to the ending of the New Deal Coalition, the issues of race and governmental policies are inseparable in America (Rose, 1995; Nuebeck and Cazenave, 2001). Within this racialized debate, Euro-Americans have historically shown higher levels of welfare contempt. In the early 1960s whites were much less likely than blacks to think that "welfare is a right" and that "welfare benefits should be larger" (Kallen and Miller, 1971). Likewise, whites in the 1980s were four times as likely to want welfare cutbacks (AuClaire, 1984). With such a legacy, the color divide has remained wide enough to induce a "race-effect" in multivariate studies of attitudes towards public welfare, Food Stamps and the minimum wage (Kleugel and Smith, 1986; Gilliam and Whitby, 1989; Hasenfeld and Rafferty, 1989; Sigelman and Welch, 1991; Cook and Barrett, 1992; Rexroat, 1993; Bobo and Kleugel, 1993; Jackman, 1994; Braham Innis and Sittig, 1996; Kinder and Sanders, 1996; Pereira and Van Ryzin, 1998; Wilson, 2000).

In emphasizing the impact of race, some research insists that class location is less consequential in minority communities. For example, two studies found that the black middle class was more supportive of public housing than the white middle class, but less supportive of such programs than the white or black working classes (Gilliam and Whitby, 1989; Wilson, 2000). Other studies suggest that racial affiliations supersede most class effects (Cook and Barrett, 1992; Braham Innis and Sittig, 1996). In these studies, blacks of all social classes are more receptive of antipoverty programs than whites. Or in the words of Hasenfeld and Rafferty (1989) "even upper class blacks are more supportive of the welfare state than are their poor white counterparts" (p. 1043). 


\section{Welfare and Racial Interpretations}

As studies link welfare attitudes to a person's race, other research has detected even stronger ties to certain racial attitudes (Iyengar, 1990; Sigelman and Welch, 1991; Bobo and Kleugel, 1993; Gilens, 1995; Entman and Rojecki, 2000). In fact, researchers such as Gilens (1999) and Peffley and Hurwitz (1998) have argued that racial attitudes are one of the best predictors of welfare sentiments. This means that the acceptance of a racial identity does not in and of itself inspire welfare generosity, but rather whites are more likely to hold the racial views that induce welfare contempt. In fact some researchers conclude that "it may be fair to say that many of the objections expressed by whites to current welfare programs were in effect antiblack biases, not always so thinly disguised" (Kallen and Miller, 1971, p. 89).

Researchers have connected welfare outlooks to different strains of racist thought. First and foremost, welfare indignation is regularly found in the "old-style" bigots who attach negative traits to an entire race (these pejorative statements are sometimes called "overt" or "Jim Crow" racism). For example, an early 1960s study discovered that women objected to welfare when they thought "Negroes are too lazy" (Kallen and Miller, 1971). Morever even as traditional prejudices have waned some in the last fifty years, the weight of Jim Crow racism remains intact. Studies from the 1980s and '90s found that welfare detractors were more prone to think that blacks were "less able to learn," "lacked will power," "disposed to violence," "lazier," and "less patriotic" (Sigelman and Welch, 1991; Bobo and Kluegel, 1993; Rexroat, 1993; Gilens, 1995; Stack, 1997; Peffley and Hurwitz, 1998; Gilens, 1999; Nelson, 1999; Entman and Rojecki, 2000; Nuebeck and Cazenave, 2001).

As researchers established the relationship between welfare condemnation and "old-fashioned" stereotypes, others highlighted the effects of less blatant biases. While fewer whites currently express these racial aspersions in public, many allege that racism no longer exists (this denial of discrimination has been called "modern " or "symbolic" racism). ${ }^{1}$ Moreover, people who minimize and downplay the presence of racial biases are less open to the expansion of Food Stamps and Medicaid programs (Iyengar, 1990; Sigelman and Welch, 1991; Bobo and Kleugel, 1993; Jacoby, 1994; Gilens, 1995; Stack, 1997). Both national and local studies have discerned that individuals were friendlier to welfare when they acknowledged "white bigotry" and "racial barriers" (Bullock, 1999; Entman and Rojecki, 2000; Kick and Fraser, 2000) or when they thought 
that "income differences are due to discrimination" and that "blacks do not have the same educational opportunities as whites" (Feagin, 1975; Sigelman and Welch, 1991; Rexroat, 1993; Kinder and Sanders, 1996; Nelson, 1999).

Another group of research links welfare resentments to complaints about "reverse discrimination" and a supposed governmental pandering to minority constituencies. In the 1960s some of welfare's loudest critics lamented that "Negroes and Jews have too much influence on the government" (Kallen and Miller, 1971), while later studies correlated welfare antipathy to the beliefs that "Negroes should not push themselves into places they are not wanted" and "blacks get more attention then they deserve" (Wright, 1977; AuClaire, 1984; Kluegel and Smith, 1986; Kinder and Sanders, 1996). Thus, a noticeable section of the white populace rant about welfare travesties since these programs supposedly help minorities at the expense of whites.

\section{Gender Statuses and Welfare Convictions}

While neither gender unequivocally defends welfare, some research has identified a small "gender gap" (Conover, 1988; Deitch, 1988; Tolleson Rinehart, 1992; Stack, 1997). In bivariate analysis, women seem slightly less likely to complain about welfare expenses (Alston and Dean, 1972; AuClaire, 1984; Conway et al., 1997). For example, in $199221 \%$ of women and $13 \%$ of men wanted an increase in welfare spending (Clark and Clark, 1996). Moreover, numerous studies suggest that gender differences remain significant after multivariate computations (Kluegel and Smith, 1986; Conover, 1988; Deitch, 1988; Gilliam and Whitby, 1989; Jackman, 1994; Braham Innis and Sittig, 1996; Pratto, Stallworth and Sidanius, 1997; Schlesinger and Heldman, 2001). For example, women of all races and classes thought the government should spend more on welfare in Illinois, Kansas and Rhode Island (Burns and Schumaker, 1987; Bullock, 1999; Sotirovic, 2000).

At the same time, not all researchers are convinced that women are essentially or automatically more supportive of welfare. A Detroit sample attained significance between gender and welfare spending inclinations in simple correlations, but this significance disappeared when race, age, income, and poverty beliefs were added to the regression (Hasenfeld and Rafferty, 1989). Likewise, two studies found that black and Latina women were somewhat more agreeable to welfare spending 
but this significance evaporated when a multiple regression controlled for age, income, marital status and other independent variables (Welch and Siegelman, 1989; Montoya, 1996).

\section{Gender Roles and Welfare Impressions}

From the inception of public welfare to the present, welfare debates have been enmeshed with visions of "proper" female sexuality and motherhood (Rose, 1995; Abramovitz, 1996; Nuebeck and Cazanave, 2001). Subsequently, a few researchers have revealed that welfare's greatest critics seem to hold conventional definitions of gender norms and motherly duties (Conover, 1988; Deitch, 1988; Cook and Wilcox, 1991; Tolleson Rinehart, 1992; Jackman, 1994; Montoya, 1996). These studies suggest that females opt for more punitive welfare rules when they believe that "husbands should make more income than their wives," "wives should focus on household chores" and a "woman's place is in the home" (Deitch, 1988; Tolleson Rinehart, 1992). Likewise, men were less charitable to welfare when they disavowed egalitarian households and rejected a mother's desire to work outside of the home (Cook and Wilcox, 1991; Jackman, 1994; Conway et al., 1997).

Conversely, welfare backers seem less wedded to traditional gender expectations (Conover, 1988; Deitch, 1988; Cook and Wilcox, 1991; Tolleson Rinehart, 1992; Conway et al., 1997). First, women who recognize and disdain sexual inequities, such as unfair hiring practices or the prevalence of sexual harassment, were usually friendlier to welfare spending (Kluegel and Smith, 1986; Clark and Clark, 1996; Conway et al., 1997; Kick and Fraser, 2000). Second, welfare supporters are more likely to adopt the feminist goals of creating greater access to child care, stopping domestic violence, and ending sexist salary discrepancies (Deitch, 1988; Iyenger, 1990). Third, positive evaluations of the woman's movement boosts a woman's approval of wider social service spending (Clark and Clark, 1996; Conway et al., 1997; Mattel, 2000), as does the internalization of the feminist label (Conover, 1988; Cook and Wilcox, 1991; Clark and Clark, 1996; Conway et al., 1997). Finally, women of affluent classes were fonder of Affirmative Action and fair wage campaigns when they expressed some solidarity with women of more disadvantaged classes (Bennett and Bennett, 1992; Tolleson Rinehart, 1992; Conway et al., 1997). 


\section{Control Variables}

Since class, race and gender cannot be the only salient factors for welfare sentiments, this study also contains seven control variables which have been predictive in previous welfare studies.

Collective Responsibility: Much of the "self-interest" research assumes that individuals are primarily self-serving egotists who are indifferent to other people's misery. While this impulse may be common, an attachment to rugged individualism is not universal and not all Americans are preoccupied with personal finances. Instead, humans can emphasize the principles of communal interdependence, shared concerns, and collective responsibilities. In turn, these altruistic positions can fuel the acceptance of governmental efforts that ensure all basic material needs are met (Kleugel and Smith, 1983; Hasenfeld and Rafferty, 1989; Feldman and Zaller, 1992; Kinder and Sanders, 1996; Schlesinger and Heldman, 2001).

Authoritarianism: Earlier it was argued that the endorsement of economic inequalities adds to greater welfare animosities. However, it is possible that this formulation is too specific since the underlying cause may be the general acceptance of institutional hierarchies. That is, people might see no rationale for welfare if they believe that leaders are trustworthy and subordinates should accept their lots without any displays of discontent. In fact, some studies suggest that welfare opponents bless social dominance (Pratto, Stallworth and Sidanius, 1997), belittle democratic processes (McCloskey and Zeller, 1984; Hasenfeld and Rafferty, 1989) and display authoritarian tendencies (Kallen and Miller, 1971).

Libertarianism and Tax Grievances: Conservative pundits regularly lament about over-taxation. Americans who air such tax gripes seem less sympathetic to the plights of welfare recipients (Feldman and Zaller, 1992; Zucker and Weiner, 1993) and are more reluctant to spend on welfare (AuClaire, 1984; Cook and Barrett, 1992; Gilens, 1995).

Urban-Rural Divides: Welfare cleavages can also occur between urban and rural peoples. Some studies suggest that rural women were more adverse to Affirmative Action (Stack, 1997) and rural residents were less sympathetic to the plights of welfare recipients (Camasso and Moore, 1985). Likewise, some studies indicate that rural peoples showed greater opposition to welfare spending (Deitch, 1988; Gilliam and Whitby, 1989) and were more likely to support work requirements for welfare mothers (Davis, 1988; Rexroat, 1993). 
Regional Biases: Southern states have the stingiest welfare packages and some studies suggest that Southerners are more disparaging of such programs (Kluegel and Smith, 1986; Gilliam and Whitby, 1989; Bobo and Kluegel, 1993; Wilson, 2000) and more willing to apply sterner welfare rules (Rexroat, 1993; Carmines and Layman, 1998).

Age: While the role of age does not show consistent results, some studies concluded that people under 40 were more likely to back greater welfare allocations (Alston and Dean, 1972; Feagin, 1975; Gilens, 1999), while people over 50 showed greater misgivings towards welfare spending (AuClair, 1984; Deitch, 1988; Gilliam and Whitby, 1989; Hasenfeld and Rafferty, 1989; Bennett and Bennett, 1992; Gilens, 1995; Braham Innis and Sittig, 1996; Montoya, 1996).

Marital Status: A few studies have identified some connections between welfare positions and family arrangements (Gilens, 1990). For example, people with offspring accepted greater welfare work requirements than childless adults (Davis, 1988) and married parents were tighter in their welfare spending opinions than single mothers (Deitch, 1988).

As this literature review indicates, the research into welfare attitudes has developed many sorts of explanations. Moreover, each of these theoretical renditions have yielded some empirical confirmations. Nevertheless, such renditions can be a bit misleading since they are usually limited by a reductionistic bent. That is, much of this research is bound to a certain set of explanatory variables and neglectful of the others. In adopting a more synthetic approach, the rest of this paper will delineate how the class, race, gender and other factors fared under multivariate conditions.

\section{RESEARCH METHODS}

\section{Sampling}

To attain some theoretical breadth, a reliance on secondary data sets was impossible. With the familiar standbys of GSS or NES skipping relevant gender questions, this analysis emerges from an original survey of college students (distributed the Fall of 2000). While collegiate studies regularly restrict themselves to a single campus, this study visited 12 US colleges. In creating a stratified sample, this study initially separated all public campuses into research, doctoral, masters or baccalaureate clusters (using the Carnegie Classification of Institutions of 
Higher Education). This creation of four clusters enabled access to students from many sorts of colleges (from large research campuses to smaller state-ran commuter colleges). Next, three schools were randomly selected from each of the four stratums ${ }^{2}$.

After selecting these twelve colleges, the author contacted faculty from each institution (via e-mail). Professors in the natural sciences, humanities, social sciences, and business were asked to administer surveys in their classrooms since student attitudes have previously differed by such majors (Astin, 1993; Milem, 1994). With participation being purely voluntary, 28 of the 338 contacted professors decided to distribute and collect the surveys during one of their class sessions $(8.2 \%){ }^{3}$

In the end, 575 students completed the survey. Although this study strived for equal representation of all academic areas, the proportion of Physical Science majors is a bit skewed (Business $n=133$, Social Sciences $n=112$, Humanities $n=105$, Natural Science $n=61$ ). Moreover, this sample has a higher proportion of women since these colleges enroll more women and more men gravitate to the natural sciences (32\% male and $68 \%$ female). The sample also has a high percentage of rural residents since several of the commuter schools are located far from any major cities (i.e., only $25 \%$ of the students claim to be from large metropolitan areas while $36 \%$ come from small towns or rural backgrounds). However, the racial breakdown seems to mirror that of many public institutions since $86 \%$ of the sample was Euro-American, $7 \%$ was African-American, 3\% was Latino(a) and 2\% was Asian-American. Likewise, the age pyramid conforms to familiar trends since the mean age was 23.7 years old and $69 \%$ of the students were between 18 and 22 years old (standard deviation equals 7.1 and the mode was 20 years old). Finally, this sample presents a very middle-class character since $21 \%$ of the students came from families with incomes of $\$ 50,000$ to 80,000 and $13 \%$ of student belonged to families with incomes of $\$ 81,000$ to 100,000 .

\section{Measures}

The survey collected information on general political attitudes. Almost every item elicited responses through a five-point Likert scale (Strongly Agree to Strongly Disagree). In the standard fashion, these responses were coded with scores of 1 to 5 (Strongly Agree generally equaled 5). The more idiosyncratic coding procedures will be described in the ensuing passages. 
Welfare Spending Preference: To identify budgetary dispositions, the survey presented the statement "The government is spending too much money on welfare" (to express welfare generosity, Strongly Disagree was recorded as a 5). Being a modified version of a commonly used measure, this question should not present any major reliability or validity concerns (Alston and Dean, 1972; AuClaire, 1984; Sigelman and Welch, 1991; Montoya, 1996; Nelson, 1999; Bullock, 1999).

Class Location: Class standing was determined through a family income scale (there were 10 categories that started at under $\$ 10,000$ and ended with above $\$ 151,000)$. Although income is not a perfect class measure, subjective measures seem problematic since most Americans call themselves middle class. Likewise, the validity of occupational classification schemes are highly disputed and some research suggests that family income has the largest impact of all class measures (Gilens, 1995; Pereira and Van Ryzin, 1998).

Stratification Belief: This measure focused on the acceptability of current wealth outcomes (Feldman and Zaller, 1992; Bobo and Kleugel, 1993; Zucker and Weiner, 1993). The extent of economic legitimacy was gauged through the statement: "Economic wealth is unjustly distributed in the United States" (Strongly Disagree = 5).

Racial Status: Race was determined by their response to the question of "how would you classify your race/ethnicity." Although it is beneficial to scan the variance by all races, the small number of Asian, Latino(a) and Native-American students led to the binary coding of Whites $=1$ and Others $=0$. Moreover, previous research suggests that whites are usually the most anti-welfare racial grouping (i.e., Kleugel and Smith, 1986; Sigelman and Welch, 1991; Kinder and Sanders, 1996).

Racial Attitudes: In focusing on "symbolic" and "modern" racism, this two-item index was pulled from the Modern Racism Scale (McConahay et al., 1981) and the Racial Ambivalence Scale (Katz and Hass, 1988). The first item minimized racial biases: "Minorities frequently see racism where it does not exist." The second item dealt with the perceived loss of fairness of employment opportunities for whites: "Due to social pressures, firms frequently have to hire unqualified racial minorities" (Cronbach Alpha of .643).

This focus on modern racism rests on several justifications. With space limitations surveys cannot address every pertinent aspect of racial attitudes (i.e., old fashioned or aversion racism). More importantly, the denial of contemporary discrimination and resentment seem especially important to welfare attitudes (Sigelman and Welch, 1991; Gilens, 
1995; Kinder and Sanders, 1996; Bullock, 1999; Entman and Rojecki, 2000). In fact, some early detractors of modern racism theory recently conceded that "symbolic racism has the far stronger effect" on policy preferences (Sears, Hetts, Sidanius and Bobo, 2000).

Gender Status: After asking "what is your sex," all females were given 1 and males received 0 .

Traditional Gender Roles: This three-item index covered the dayto-day prescriptions on how men and women should live (Cronbach Alpha .676). While gender roles encompass many judgments, traditional gender expectations and early welfare policies have prioritized the worth of male labor. Accordingly, the survey announced that: "There are circumstances in which women should be paid less than a man for equal work" (Morgan, 1996). With traditional images condoning patriarchal control and the subordination of wives and daughters, the instrument declared: "It is a man's duty to maintain order in his family" (Henley et al., 1998). Finally, traditional gender scripts contend that "pure" women are virgins who never act on sexual desires. Additionally, if a rape or harassment occurs, there is a suspicion that the women somehow induced the sexualized aggression. Thus, the third item blamed women for such violence: "In some ways women provoke rape by their appearance or behaviors" (Ashmore et al., 1995).

Feminist Identities: Feminists recognize systematic gender biases before they repudiate and challenge such inequities through collective political advocacy (Tolleson Rinehart, 1992; Morgan, 1996; Conway et al., 1997). Subsequently, the first item connected social rights to gender classifications: "Stereotypes about women have not affected me personally." The second item dealt with a liberal feminist position on work rights: "A woman should have the same job opportunities as a man" (Morgan, 1996). The next statement expressed a radical depiction of male dominance and exploitation: "The way to eliminate prostitution is to make women economically equal to men" (Henley, Meng, O'Brein, McCarthy and Sockloskie, 1998). Finally, the last three items dwelled on the necessity of feminist collective action. One item embraced a passive and assimilationist approach to social change: "If we leave society alone, eventually men and women will be treated fairly" (Morgan, 1996). Conversely, the last items dealt with a sense of activist obligations: "I see myself as someone who is involved in promoting social justice" and "If a person is not fighting against social injustice, then they are part of the problem" (Cronbach .610).

Self-Interest/Collective Responsibility: In contrast to the doctrine of rugged individualism, some Americans express a sense of communal 
interconnectedness and collective commitments. In emphasizing a sense of mutuality and community concerns, this item read "A good society is one in which people feel responsible for each other" (Katz and Hass, 1986).

Authoritarian Inclinations: This scale took three items from Atlemeyer's (1990) Right-Wing Authoritarianism scale (Cronbach Alpha .627). The first item focused on faith in societal leaders: "Authorities generally turn out to be right about things" and the second item urged compliance to legal statutes: "Law and Order ought to be strengthened in our society." The last question focused on tolerance of public dissent: "I get angry when I hear people criticizing the United States."

Tax Grievances: The statement "Americans pay too much taxes" was used to identify the extent of perceived tax improprieties.

Marital Status: Responses were recorded as being single or not (Single $=1$, Other $=0$ ). This choice was based on the fact that being single is what usually differentiates people in welfare studies.

Age: One's age was ascertained through the open ended question: "What is your age?"

Southern Residence: In using Bobo and Kluegel's (1993) geographical categories, students who attended Southern colleges were deemed Southern.

Rural Residence: To find the urbanity of the crowd, one question asked: "What is the type of community that you spent most of your youth?" Those who answered rural and small town were considered rural, while other answers were deemed non-rural (Rural, Small Town = 1 , Other $=0$ ).

\section{FINDINGS}

\section{Descriptive Findings}

Instead of finding a broad consensus, student opinion seemed split on this issue (see Appendix A). While the distribution was not perfectly symmetrical, the division between welfare backers and opponents was close $(41 \%$ to $31 \%)$ and sightly more liberal (mean $=2.8)$. However, this polarization is not that severe or intense since most students offered neutral or mild opinions (the response of Agree, Not Sure and Disagree netted between $77 \%$ of the respondents, Not Sure was the modal score and the Agree/Disagree totals were almost identical). Thus the slightly more 
generous tilt was mostly due to the fact that the few Strongly Disagrees were almost doubled by the number of Strongly Agrees (15\% to 8\%).

\section{Explanatory Analysis}

To deal with issues of competing theoretical camps, this analysis ran four OLS regressions. To begin with, Model 1 limits itself to an analysis of only class variables. The later models of two through four merge different sets of race, gender and control factors into the multivariate. The advantages of this approach are numerous. This technique keeps similar variables together, controls for the effects of the other independent variables and accounts for the accumulative impact for all of the variables entered. Finally, this sequential approach highlights the additional explanatory power of the newly added model (F-Score Change indicates whether the new model contributed a significant amount of explained variance).

In Table 1, the first column with figures displays the scores for the class variables. The columns to the right contain the calculations after the new batches were merged into the model. Similar to the typical regression, the cells in the middle of the table report the standardized coefficients for each variable. Near the bottom of the table rests the significance tests for the accumulative effects of all entered variables (through the familiar R-square and F-score calculations). The last row determines the unique contributions of the newly added variables (F-Change).

When exploring the class variables by themselves, Model 1 netted some significant results. In bearing negative coefficients, higher incomed peoples were more inclined to restrict welfare as were those who lauded current wealth allocations. However, this stratification belief seems more important since its beta weight was almost twice as large as the objective class measure. Finally, this combination of class factors was strong enough to explain $18 \%$ of the variance in welfare attitudes and had the impressive overall F-score of 63.017.

When including the race variables, some further insights emerged. The impact of racial status was too small to meet statistical significance. Conversely the significance of racial interpretations seems indisputable. In presenting the strongest association, welfare critics disputed the presence of racial biases and considered Affirmative Action a nuisance. Moreover, modern racism boosted the explanatory power by 12 points and presented a large F-change of 20.582. At the same time, the impact of racial outlooks did not render the class variables insignificant. Thus, 
TABLE 1. Regression of Welfare Spending Attitudes on Class, Race, Gender and Control Variables

\begin{tabular}{|c|c|c|c|c|}
\hline Variables & Model 1 Class & $\begin{array}{l}\text { Model } 2 \\
\text { Class + Race }\end{array}$ & $\frac{\text { Model } 3 \text { Class }+ \text { Race }+}{\underline{\text { Gender }}}$ & $\frac{\underline{\text { Full Model }}}{\text { Class + Race }+}$ \\
\hline $\begin{array}{l}\text { Class } \\
\text { Income } \\
\text { Stratification Belief }\end{array}$ & $\begin{array}{l}-.182^{\star \star \star} \\
-.351^{\star \star \star}\end{array}$ & $\begin{array}{l}-.150^{\star \star \star} \\
-.249^{\star \star \star}\end{array}$ & $\begin{array}{l}-.120^{\star \star \star} \\
-.172^{\star \star \star}\end{array}$ & $\begin{array}{l}-.088^{\star \star} \\
-.136^{* \star \star}\end{array}$ \\
\hline $\begin{array}{l}\text { Race } \\
\text { White } \\
\text { Modern Racism }\end{array}$ & & $\begin{array}{l}-.021 \\
-.366^{\star \star \star}\end{array}$ & $\begin{array}{l}-.021 \\
-.241^{\star \star *}\end{array}$ & $\begin{array}{l}-.015 \\
-.194^{\star \star \star}\end{array}$ \\
\hline $\begin{array}{l}\text { Gender } \\
\text { Female } \\
\text { Traditional Gender Roles } \\
\text { Feminist Identity }\end{array}$ & & & $\begin{array}{r}.055 \\
-.165^{\star \star \star} \\
.212^{\star \star \star}\end{array}$ & $\begin{array}{r}.029 \\
-.129^{\star \star \star} \\
.172^{\star \star \star}\end{array}$ \\
\hline $\begin{array}{l}\text { Controls } \\
\text { Collective Responsibility } \\
\text { Authoritarianism } \\
\text { High Tax Grievance } \\
\text { Single } \\
\text { Age } \\
\text { Southern Residence } \\
\text { Rural Residence }\end{array}$ & & & & $\begin{array}{l}-.057 \\
-.141^{\star \star \star} \\
-.098^{\star \star} \\
-.034 \\
-.069 \\
-.007 \\
-.014\end{array}$ \\
\hline $\begin{array}{l}\text { Constant } \\
\text { Overall R-Squared } \\
\text { Overall F-Score } \\
\text { F-Score Change }\end{array}$ & $\begin{array}{c}3.90 \\
.181 \\
63.017^{\star \star \star}\end{array}$ & $\begin{array}{c}4.99 \\
.300 \\
61.044^{\star \star \star} \\
20.582^{\star \star \star}\end{array}$ & $\begin{array}{c}4.81 \\
.350 \\
45.235^{\star \star \star} \\
5.732^{\star \star \star}\end{array}$ & $\begin{array}{c}3.922 \\
.382 \\
26.393^{\star \star \star} \\
1.941^{\star}\end{array}$ \\
\hline
\end{tabular}

Numbers reported are standardized Beta Coefficients.

${ }^{*} p<.05^{\star *} p<.01^{* * *} p<.001$

to this point, it seems that welfare antagonism was not predicated on being white, but rather welfare critics were the more affluent peoples who considered their prosperity as being justified since racial minorities supposedly encounter no disadvantages.

The gender model adds two pivotal factors. While gender did not offer a significant impact, the adherence to traditional gender expectations inhibited welfare generosity. In effect, people felt no compulsion to raise welfare spending when they blamed women for rape and wanted stay-at-home mothers. Conversely, men and women with feminist identities were some of the sample's strongest welfare proponents. That is, current welfare budgets seemed meager when people observed gender injustices and felt the necessity of acting politically on the behalf of women. With the gender sensibilities nudging the r-squared from .300 to .350 , their unique contribution netted the significant F-Change of $5.732(\mathrm{p}<.001)$. On the other hand, the gender variables did not dramatically mitigate the other variable impacts since class and race factors re- 
mained significant at the same alpha levels and their beta weights shrunk only slightly.

The merging of the control variables did not bring many significant variables. Only the factors of authoritarian orientations and tax complaints netted any significance while the demographic qualities of marital status, age and place of residence did not encourage any distinctive welfare philosophies. However, the impact of an authoritarian outlook is considerable since its coefficient was larger than the income measure and rivaled the items on gender roles and stratification beliefs. Subsequently, the influences of the authoritarian and tax perspective were noticeable enough to create a F-Change of $1.941(\mathrm{p}<.05)$. Lastly, the inclusion of these new variables did not seriously alter the relationships of most of the previously significant variables. That is, the acceptance of modern racism and feminist perspectives remained the most powerful variables followed by the next tier of authoritarianism, gender role prescriptions and stratification beliefs. However, income lost enough strength to fall into a lower level of statistical significance (from .001 to $.01)$.

\section{CONCLUSION}

This paper set out to understand the nature of American welfare-spending preferences. In seeking an exhaustive model, this study drew upon several theoretical camps. This broad-based approach seems beneficial since welfare attitudes stemmed from many sources. That is, welfare attitudes appear to be an amalgamation of many sorts of political and social beliefs.

The study confirmed the influence of class locations since people with higher incomes were more conservative in their spending priorities. Moreover stratification beliefs are equally crucial since people of all classes were more likely to embrace smaller welfare appropriations when they laud current wealth allocations. This means, that poor people with a reverence for wealth will not instinctively choose expansive welfare budgets, nor will affluent people berate welfare if they think wealth is unjustly appropriated.

Although class had predictive qualities, it was not the only catalyst behind welfare austerity. While race by itself did not play a decisive role in this sample, it is clear that welfare apprehensiveness is heavily "encoded" with racial subtexts. That is, among all of the variables in this study, the tenets of modern racism triggered the greatest amount of 
antiwelfare sentiments. In essence, the denial of racial discrimination and resentment of minority activism seem to impede any allegiance to governmental forms of welfare.

While racial messages are woven into welfare thoughts, so are the conceptions of gender norms. Being a woman did not inspire any unique welfare perspectives but the acceptance of traditional gender roles encouraged welfare reductions while the presence of a feminist consciousness did the opposite. That is, both males and females were less inclined to support welfare when they endorsed salary discrepancies, a father dominated family and the notion that women are to be blamed for rape. Meanwhile, people who recognized, disliked, and challenged sexual hierarchies were much less accepting of Spartan welfare budgets.

When exploring the control variables, it seems that welfare adversaries think that tax burdens are too high and they desire a communal deference to authority figures. Antithetically the other control variable seems less crucial to the welfare debate. When in a multivariate analysis, a generic empathy for others seems irrelevant to welfare deliberations as does being single, younger, Southern or from a rural locale.

In taking these findings as a whole, a set of important predictors emerges. Rather than conceiving welfare contempt through a single lens of class, race or gender, it seems wiser to assume that all of these factors provide a separate and distinct contribution to such objections (or in other words, some class, race and gender variables presented direct additive effects when the other variables were held constant). More precisely, people are more likely to favor smaller welfare allocations when they have greater incomes, retain authoritarian beliefs, abhor paying taxes, believe in economic meritocracies, dismiss the existence of racism, feel cheated by Affirmative Action, seek traditional gender roles, and distance themselves from feminism. Conversely other factors did not offer significant effects on welfare assessments (being white, male, single, younger and living in Southern or rural areas). Subsequently, this work highlights both the importance of one's class standing and how one interprets the presence of American inequalities. This work clearly supports the "self-interest" hypothesis. Poorer people, regardless of their attributional processes, are more likely to embrace expanding welfare budgets. Moreover, the variable of communal responsibility did not mitigate the welfare biases that are common for the different social stratums. Along ideological lines, citizens of all races and genders seem to prefer smaller welfare budgets when they revere authority figures and accept the traditional patterns of class, race and gender privileges. Conversely, expanding welfare appro- 
priations seems reasonable when individuals detect some injustices in class, race and gender arrangements. Moreover, this work challenges the arguments that women and racial minorities are automatically more sympathetic to welfare because of their gender or racial classifications. Instead gender gaps and racial cleavages appear because women and people of color are generally paid less and/or they are more aware of the inequities that are built into the status quo.

In ending this article, I hope this study spurs further research. It would be interesting to see if these results are replicated with other research designs. The use of cross-sectional data begs the question as to whether these findings would hold up under longitudinal conditions. For example, other works have found greater levels of welfare animosity in the early 1990s. Thus, this study might indicate a slight movement towards greater welfare generosity in the post welfare reform years (1996 and later). Conversely, the meaning of the data might not be that clear since the use of student samples raises questions of representativeness. Without comparative data, it is impossible to know if college students show more liberal welfare preferences than the general population. Along similar lines, one might wonder if the lack of significance for race, age and marital variables could be due to the unique qualities of a college sample (i.e., the general population has a larger number of married adults and greater diversity in racial and age matters). Researchers might also want to modify some of the study's measures. One can explore other dimensions of welfare attitudes or operationalize being Southern or rural in other ways. It is possible the effects of racial or feminist attitudes could have been stronger if we tracked different aspects of racism or sexism (i.e., issues of child care, domestic violence, or the racial biases in law enforcement and banking). ${ }^{4}$ Likewise, a different coding of race or class might elicit other results.

In addition to these methodological concerns, the next wave of studies should add new variables. They might ask respondents if they ever received welfare or if they have any young children in their family (Cook and Barrett, 1992; Pereira and Van Ryzin, 1998). Likewise, they might explore their knowledge about actual welfare policies or the racial characteristics of welfare recipients (Iyengar, 1990; Cook and Barrett, 1992; Littrell and Diwan, 1998; Peffley and Hurwitz, 1998). Finally, researchers can provide subtler understandings if they move the causal link back a few steps. That is, rather than simply looking at the dispositions of individuals, research can explore the pull of certain situational and contextual trappings. For example, they can ascertain if certain media stimuli augment previously held welfare attitudes (Iyengar, 1991; Entman and Rojecki, 2000; Sotirovic, 2000) or if political leaders 
can fan welfare resentments (Kinder and Sanders, 1996). Moreover, researchers can borrow variables from the political socialization literature which identifies the ways in which the immediate settings of family and schooling can sway political attitudes.

Regardless of how this research is used, one thing seems clear. With measures from each camp making explanatory contributions, this study suggests that the effects of these class, race and gender variables do not override or cancel out the influence of the other. Instead, welfare hostility seems to be a narrative which weaves some of the most hierarchical elements of class, race and gender perceptions into a coherent worldview.

\section{NOTES}

1. In the last fifty years, Americans have shown a dramatic decline in voicing of old fashioned racism. For example, in the 1940s, 55\% of whites thought whites should have the first chance at any sort of job, but only 3\% thought the same thing in 1972 (Sears et al., 2000). However, these changes have not been accompanied with a comparable change in widespread enthusiasm for anti-discrimination programs.

2. Research schools: University of Delaware, University of Oregon, University of Texas; Doctoral: University of North Carolina-Greensboro, University of Mass-Lowell, Rutgers; Masters: Longwood College, University of Southern Maine, University of Wisconsin-Green Bay; Baccalaureate: Evergreen State College, Mesa State College, Southeast Arkansas College.

3. Clearly this response rate was not high nor random. Professors who never read e-mail automatically removed themselves from the sample and the willingness to distribute the surveys was not constant throughout the different sorts of schools and disciplines. Around $2 \%$ of the Research professors distributed surveys, while $13 \%$ professors at masters granting universities did so. Likewise, less than $1 \%$ of Chemistry, Biology, and Physics profs assisted in this project while professors in Political Science, Sociology, and Social Work were most receptive to my requests $(11 \%)$.

4. Although I consider my measures generally sound, the parallel or internal-consistency of the scales were not as high as one might want. Likewise, some of the scales could have missed some vital dimensions of a given variable (i.e., stratification beliefs could have directly measured individualistic explanations of poverty).

\section{REFERENCES}

Abramovitz, M. (1996). Regulating the lives of women. Boston: South End Press.

Alston, J., \& Dean, I. (1972). Socioeconomic factors associated with attitudes towards welfare recipients and the causes of poverty. Social Service Review 46, 13-24.

Altemeyer, B. (1990). Enemies of freedom. San Francisco: Jossey-Bass.

AuClaire, P. (1984). Public attitudes towards social welfare expenditures. Social Work 29, 139-44. 
Braham-Inniss, L., \& Sittig, J. (1996). Race, class, and support for the welfare state. Sociological Inquiry 66, 175-196.

Bennett, S., \& Bennett, L. (1992). From traditional to modern conceptions of gender equality in politics. Western Political Quarterly 45, 123-45.

Bobo, L., \& Kleugel, J. (1993). Opposition to race targeting: Self-interest, stratification ideology, or racial attitudes? American Sociological Review 58, 443-464.

Bullock, H. (1999). Attributions for poverty: A comparison of middle-class and welfare recipients attitudes. Journal of Applied Social Psychology 29, 2059-2082.

Burns, N., \& Schumaker, P. (1987). Gender differences in attitudes about the role of local government. Social Science Quarterly 68, 138-47.

Camasso, M., \& Moore, D. (1985). Rurality and the residentialist social welfare response. Rural Sociology 50, 397-408.

Carmines, E., \& Layman, G. (1998). When prejudice matters: The impact of racial stereotypes on the racial policy preferences of democrats and republicans. In J. Hurwitz \& M. Peffley (Eds.), Perception and prejudice: Race and politics in the United States (pp. 100-134). New Haven: Yale University Press.

Clark, J., \& Clark, C. (1996). The gender gap: A manifestation of women's dissatisfaction with American polity. In S. Craig (Ed.), Broken contract (pp. 167-183). Boulder, CO: Westview Books.

Conover, P. (1988). Feminists and the gender gap. Journal of Politics 50, 985-1009.

Conway, M., Steuernagel, G., \& Ahern, D. (1997). Women and political participation. Washington, CQ Press.

Cook, E., \& Wilcox, C. (1991). Feminism and the gender gap: A second look. Journal of Politics 53, 1111-1123.

Cook, F., \& Barrett, E. (1992). Support for the American welfare state. NY: Columbia University Press.

Davis, L. (1988). Rural attitudes toward women, work and welfare. Affilia 3, 69-79.

Deitch, C. (1988). Sex differences in support for government spending. In C. Meuller (Ed.), in Politics of the gender gap (pp. 192-217). Beverly Hills: Sage.

Entman, R., \& Andrew, R. (2000). The black image in the white mind. Chicago: University of Chicago Press.

Feagin, J. (1975). Subordinating the poor. Englewood Cliffs, NJ: Prentice Hall.

Feldman, S., \& Zaller, J. (1992). The political culture of ambivalence: Ideological responses to the welfare state. American Journal of Political Science 36, 268-307.

Gilens, M. (1995). Racial attitudes and opposition to welfare. Journal of Politics 57, 999-1014.

Gilens, M. (1999). Why Americans hate welfare: Race, media, and the politics of antipoverty policy. Chicago: University of Chicago Press.

Gilliam, F., \& Whitby, K. (1989). Race, class, and attitudes toward social welfare spending. Social Science Quarterly 70, 80-99.

Hasenfeld, Y., \& Rafferty, J. (1989). The determinants of public attitudes toward the welfare state. Social Forces 67, 1027-1048.

Henley, N., Meng, K., O’Brien, D., McCarthy, W., \& Sockloskie, R. (1998). Developing a scale to measure the diversity of feminist attitudes. Psychology of Women Quarterly 22, 317-348.

Iyengar, S. (1990). Framing responsibility for political issues: The case of poverty. Political Behavior 12, 19-40. 
Jackman, M. (1994). The velvet glove. Berkeley: University of California Press.

Jacoby, W. (1994). Public attitudes toward government spending. American Journal of Political Science 38, 336-361.

Kallen, D., \& Miller, D. (1971). Public attitudes toward welfare. Social Work 16, 83-90.

Katz, I., \& Hass, G. (1986). Racial ambivalence and racial value conflict. Journal of Personality \& Social Psychology 55, 893-905.

Kick, E., \& Fraser, J. (2000). An examination of support or non-support for affirmative action, race-targeted and income targeted policies. Journal of Poverty 4, 43-71.

Kinder, D., \& Sanders, L. (1996). Divided by color: Racial politics and democratic ideals. Chicago: University of Chicago Press.

Kluegel, J., \& Smith, E. (1986). Beliefs about inequality. New York: Aldine De Gruyter.

Krinsky, J. (2001). Work, workfare, and contention in New York City. Critical Sociology 24, 277-305.

Mattle, F. (2000). The gender gap in presidential elections. Polity 33, 199-225.

McConahay, J., Hardee, B., \& Batts, V. (1981). Has racism declined in America? Journal of Conflict Resolution 25, 563-579.

McCrate, E., \& Smith, J. (1998). When work doesn't work: The failure of current welfare reform. Gender and Society 12, 61-80.

Montoya, L. (1996). Latino gender differences in public opinion. Hispanic Journal of Behavioral Sciences 18, 255-276.

Morgan, B. (1996). Putting the feminism into feminism scales: Introducing the liberal feminist attitude and ideology scale. Sex Roles 35, 359-89.

Nelson, T. (1999). Group affect and attribution in social policy opinion. Journal of Politics 61, 331-363.

Nuebeck, K., \& Cazanave, N. (2001). Welfare racism: Playing the race card against America's poor. New York: Routledge.

Peffley M., \& Hurwitz, J. (1998). Whites' stereotypes of blacks: Source and political consequences. In J. Hurwitz \& M. Peffley (Eds.), Perception and prejudice: Race and politics in the United States (pp. 58-99). New Haven: Yale University Press.

Pereira, J., \& Van Ryzin, G. (1998). Understanding public support for time limits and other welfare reforms. Public Studies Journal 26, 398-418.

Pratto, F., Stallwoth, L., \& Sidanius, J. (1997). The gender gap: Difference in political attitudes and social dominance orientation. British Journal of Social Psychology 36, 49-68.

Reese, E. (2002). Resisting the workfare state. Race, Gender \& Class 9, 72-95.

Rexroat, C. (1993). Race, work, and welfare: Attitudes towards the required employment of young mothers who use welfare. Population Research and Policy Review $12,123-138$.

Rose, N. (1995). Workfare or fair work? Women, welfare and government work programs. New Brunswick: Rutgers University Press.

Sclesinger, M., \& Heldman, C. (2001). Gender gap or gender gaps? New perspectives on government action and policies. Journal of Politics 63 (1): 5992.

Sears, D., Hetts J., Sidanius, J., \& Bobo, L. (2000). Race in american politics. In D. Sears, J. Sidanius, and L. Bobo (Eds.), Racialized politics (pp. 1-43). Chicago: University of Chicago Press. 
Shapiro, R., \& Mahajan, H. (1986). Gender differences in policy preferences. Public Opinion Quarterly 50, 42-61.

Sigelman, L., \& Welch, S. (1991). Black Americans' views on racial inequality. Nwe York: Cambridge Press.

Snelling, S. (1999). Women's perspectives on feminism. Psychology of Women Quarterly 23, 247-67.

Sotirovic, M. (2000). Effects of media use on audience framing and support for welfare. Mass Communication and Society 3, 269-296.

Stack, S. (1997). Women's opposition to race-targeted interventions. Sex Roles 36, 543-550.

Tolleson Rinehart, S. (1992). Gender consciousness and politics. New York: Routledge.

Welch, S., \& Sigelman, L. (1989). A black gender gap? Social Science Quarterly 70, $12-133$.

Williamson, J. (1974). Beliefs about the motivation of the poor and attitudes towards poverty policy. Social Problems 2, 634-48.

Wilson, G. (2000). Race, class, and support for egalitarian statism among the African-American middle class. Journal of Sociology \& Social Welfare 37, 75-91.

Wright, G. (1977). Racism and welfare policy in America. Social Science Quarterly 57, 718-33.

Zucker, G., \& Weiner, B. (1993). Conservativism and perceptions of poverty. Journal of Applied Social Psychology 23, 925-943.

\section{APPENDIX A. Item Wording and Descriptive Statistics}

\begin{tabular}{|c|c|c|c|}
\hline Welfare Spending Preference & $\mathrm{N}$ & Mean & SD \\
\hline $\begin{array}{l}\text { The government is spending too much money on welfare. } \\
\text { Strongly Agree } \\
\text { Agree } \\
\text { Not Sure } \\
\text { Disagree } \\
\text { Strongly Disagree }\end{array}$ & $\begin{array}{r}45 \\
132 \\
160 \\
151 \\
87\end{array}$ & 2.8 & \\
\hline \multicolumn{4}{|l|}{ Stratification Belief } \\
\hline $\begin{array}{l}\text { Economic wealth is unjustly distributed in the United States. } \\
\text { Modern Racism (Cronbach Alpha }=.643 \text { ) }\end{array}$ & & 3.95 & .94 \\
\hline $\begin{array}{l}\text { Minorities frequently see racism where it does not exist. } \\
\text { Due to social pressures, firms frequently have to hire unqualified racial minorities. } \\
\text { Feminist Orientation (Cronbach Alpha }=.656 \text { ) }\end{array}$ & & $\begin{array}{l}3.06 \\
2.92\end{array}$ & $\begin{array}{l}1.09 \\
1.01\end{array}$ \\
\hline $\begin{array}{l}\text { It is a man's duty to maintain order in his family. } \\
\text { Stereotypes about women have not affected me personally. (R) } \\
\text { A woman should have the same job opportunities as a man. } \\
\text { The way to eliminate prostitution is to make women economically equal to men. } \\
\text { If we leave society alone, eventually men and women will be treated fairly. (R) } \\
\text { I see myself as someone who is involved in promoting social justice. }\end{array}$ & & $\begin{array}{l}2.10 \\
3.51 \\
4.49 \\
2.52 \\
3.94 \\
2.44\end{array}$ & $\begin{array}{r}1.16 \\
1.22 \\
.75 \\
1.08 \\
.92 \\
.96\end{array}$ \\
\hline Collective Responsibility & & & \\
\hline $\begin{array}{l}\text { A good society is one in which people feel responsible for each other. } \\
\text { High Tax Grievance }\end{array}$ & & 3.90 & .85 \\
\hline Americans pay too much taxes. & & 3.41 & 1.12 \\
\hline
\end{tabular}

